\title{
iWindCr Wireless Sensor System for Corrosion Detection and Monitoring of Offshore Wind Turbine Structures
}

\author{
Lead Author: Sarinova Simandjuntak, PhD, MSc, BEng (Hons), DIC, FHEA, CEng (MIET) \\ University of Portsmouth \\ Portsmouth, United Kingdom \\ Sarinova.Simandjuntak@port.ac.uk
}

Dr Nils Bausch and Mr Andrew Farrar, University of Portsmouth, Portsmouth, United Kingdom Nils.Bausch@port.ac.uk, andrew.farrar@port.ac.uk

Dr Juan Ahuir-Torres, Liverpool John Moore University, United Kingdom

J.I.AhuirTorres@1jmu.ac.uk

Mr Adrian Nash and Dr Bob Thomas

Avonwood Developments Ltd, Bournemouth, United Kingdom

adrian.nash@avonwood.co.uk, bob.thomas@avonwood.co.uk

Mr Joseph Muna, Mr Carl Jonsson, and Miss Diana Mathew

Avanti Communications, London, United Kingdom

joseph.muna@avantiplc.com, Carl.Jonsson@avantiplc.com, Diana.Mathew@avantiplc.com

\section{Synopsis}

The $i W i n d C r$ system, designed and developed to comprise miniaturised corrosion sensors to form a Wireless Sensor Network (WSN), has been piloted in one of the 116 offshore wind turbines located in the south region of the UK. The $i W i n d C r$ system that was equipped with low power-low current sensor interface incorporating the Open Circuit Potential (OCP) and Zero Resistance Ammeter (ZRA) electrochemical technique analysis and the Internet of Things (IoT) was employed to detect and/or monitor electrochemical activities in relation to corrosion on the surface of the M72 stud, part of the monopole (MP) foundation and transition piece (TP) flanged connection of the wind turbine. Through the utilisation of the corrosion threshold database that has been extensively generated also through this project for various materials and environment of wind turbine components, the state of corrosion or damage of the M72 stud can be determined. The provision of the corrosion threshold data could also allow for life prediction.
Keywords - Offshore, wind turbine, corrosion, Wireless sensor network (WSN), Internet of Things (IoT)

\section{Introduction}

The UK's geographical location makes it ideal for offshore wind energy, accounting for its status as a world leader in the sector. The UK Wind Energy Database [UKWED, 2019] published by Renewable UK, reported that there are currently 2,016 offshore wind turbines (WT) from 37 offshore operational projects ( $>100 \mathrm{~kW}$ projects) that have been producing an operational power capacity of approximately $8.48 \mathrm{GW}$. These turbines have already powered the equivalent of 4.5 million homes annually and are envisaged to generate over $10 \%$ of UK electricity by 2020 [RenewableUK, 2019]. This provision of clean, affordable and secure energy simultaneously would have to consider the integrity, reliability and sustainability in the operation and maintenance of the WT. Particularly when the WT main structures such as the foundation, tower, 
nacelle and blades (Figure 1) are exposed to harsh conditions generated from the wind, the weather, the ultraviolet radiation (sunlight) and the marine (ocean wave)/maritime environment. This makes corrosion is one of the inevitable and costly issues which has led to the decision of utilising specific corrosion resistance materials and protection in compliance to the industrial standards such as DNVGL-RP-0416 [DNV, 2016]. Nevertheless, corrosion in the foundation structure and its attribute and in the transition piece that connects the foundation and tower has been reported to be one of the main threats of the structural integrity of the offshore WTs. These structures typically comprise external and/or internal components and parts made of steel alloys such as low carbon steels, weathering steels as well as stainless steels [DNV, 2013]. Most parts from the splash zone upwards are coated to prevent corrosion whilst downward of the splash zone would be a combination of coating and sacrificial anodes [Black et al. 2015]. Though the coating could prevent general corrosion, some components/parts are still prone to localised corrosion that may be due to the presence of sulphur in the coating that encourages microbial corrosion, surface or passive film damage from salt spray and impact of foreign object e.g. sands, and from the operation itself e.g. friction between the connected parts [Pawsey, 2016].

Fig.1: Offshore Wind Farm in South Region, UK

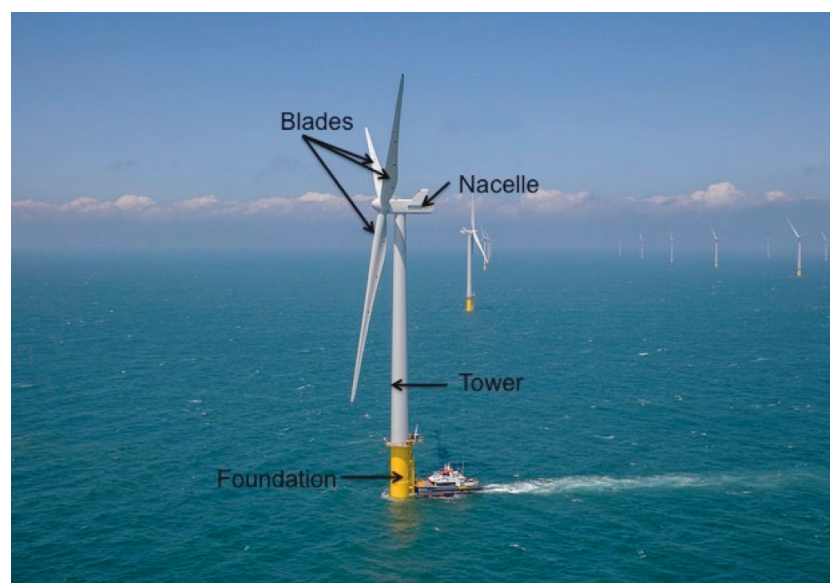

$i$ Wind $C r$ is a technology development project funded by the Innovate UK aims to develop a cost-effective end-to-end Non Destructive Testing (NDT) corrosion detection and monitoring solution for offshore WT. The system comprises miniaturised sensors arranged in a Wireless Sensor Network (WSN) suitable for being affixed to internal and/or external turbine structures. The corrosion detection thus the monitoring is based on measurement of the changes in the electrochemical states employing the Open Circuit Potential (OCP) and Zero Resistance Ammeter (ZRA) techniques. Implementing the concept of an Internet of Things (IoT) on the Sensor Interface system enables the integration of the WSN with a satellite and terrestrial telecommunication that provides guaranteed IP for data backhaul from the $i$ Wind Cr WSN on the wind farm site to the control room for analysis. [Ahuir-Torres et.al 2019] provides the overview of the $i$ Wind $C r$ design and development. As the $i W i n d C r$ system moves towards its prototyping stage, it shows that the system can be implemented in two possible scenarios, they are:

Scenario 1: Corrosion detection and monitoring system with satellite bandwidth connectivity

This allows real-time monitoring of corrosion remotely. Depending on the satellite bandwidth plan, any other data can be send/received over the satellite broadband connection thus giving an alternate, high reliability communication channel to the windfarm.

Scenario 2: Corrosion detection and monitoring system without satellite bandwidth connectivity

Under this option the data from the $i W i n d C r$ system can either be stored locally at the windfarm and retrieved periodically for analysis or accessed remotely via the user interface if connected to the internet using a terrestrial connection.

$i$ Wind $\mathrm{Cr}$ prototype has been trialled in one of the 116 offshore WTs in the UK's south region. The system was used to monitor electrochemical changes in connection to corrosion activities of one of the 84 M72 studs, in the MP-TP flanged connection of the WT. Adapting Scenario 2, an SD card was used to collect and store data over a one-month trial period. This pilot study aims to determine the reliability and stability of $i \mathrm{WindCr}$ system in the operating/field conditions and environment. The adequacy of data collection in connection to the sensor interface setting i.e. the frequency or number of reading and the quality of the reading needed for the OCP and ZRA analysis could also be assessed. The corrosion threshold database that has been developed extensively through in-house laboratory testing would be used 
to verify the readings. At the same time, this could be used to analyse the corrosion state/activities of the stud as well as for the life prediction.

\section{Pilot Study}

\subsection{M72 Stud}

An offshore wind turbine's MP-TP flanged connection consist of "bolted connection" of 84 studs made of 10.9 grade Galvanised steel alloys. The M72 class studs are used which each has $110 \mathrm{~mm}$ length across the flat area, $72 \mathrm{~mm}$ body diameter and $58 \mathrm{~mm}$ thickness. As informed by the wind turbine operator, these studs would have Molykote coating [Dow Corning, 2012] for corrosion prevention containing inorganic and organic compounds mixture such as white mineral oil and calcium hydroxide.

\section{$2.2 i$ WindCr sensor system and configuration}

$i$ Wind $C r$ sensor made of flexible PolyEther Ether Ketone (PEEK) was attached directly to the M72 stud (not on a polished surface) using silver conductive epoxy adhesive. Table 1 outlines the characteristic of the sensor.

Table 1: Sensor characteristic

\begin{tabular}{|c|c|}
\hline $\begin{array}{c}\text { Size: width X length X } \\
\text { thickness (all in } \mathrm{cm})\end{array}$ & $1.0 \mathrm{X} 1.0 \mathrm{X} 0.15$ \\
\hline Exposed Area $\left(\mathrm{cm}^{2}\right)$ & 1 \\
\hline $\begin{array}{c}\text { Molecular Mass } \\
(\mathrm{g} / \mathrm{Mol})\end{array}$ & 55.8 \\
\hline Density $\left(\mathrm{g} / \mathrm{cm}^{3}\right)$ & 8.05 \\
\hline Oxidation State $(\mathrm{e}-)$ & 3 \\
\hline $\begin{array}{c}\text { Three electrodes cell } \\
\text { system: } 1 \text { working, 1 } \\
\text { counter, and 1reference } \\
\text { electrodes }\end{array}$ & $\begin{array}{c}\text { Silver }(\mathrm{Ag}) \text { and } \\
\text { Copper }(\mathrm{Cu}) \text { wires } \\
\text { inserted in 3 laser } \\
\text { grooved sections } \\
\text { on PEEK }\end{array}$ \\
\hline
\end{tabular}

The electrode wires are connected to the sensor interface system constructed in a squared PCB of $50 \mathrm{~mm}$ X $50 \mathrm{~mm}$ X $2.0 \mathrm{~mm}$. The PCB hosts the power supply connection pads, switch and regulator; XBee or wireless communication modules; analogue to digital converters; OCP and ZRA modules and mode switches; programming port; microcontroller; and nanotimer. Figures 2 and 3 show the PCB layout and the $i$ Wind Cr sensor attachment on the M72 stud.

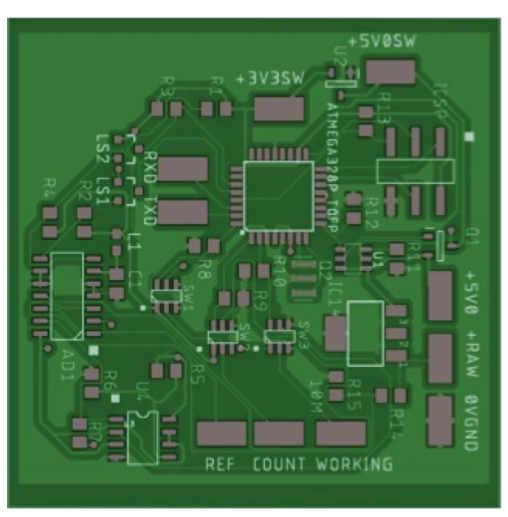

Fig. 2: PCB layout of the sensor interface

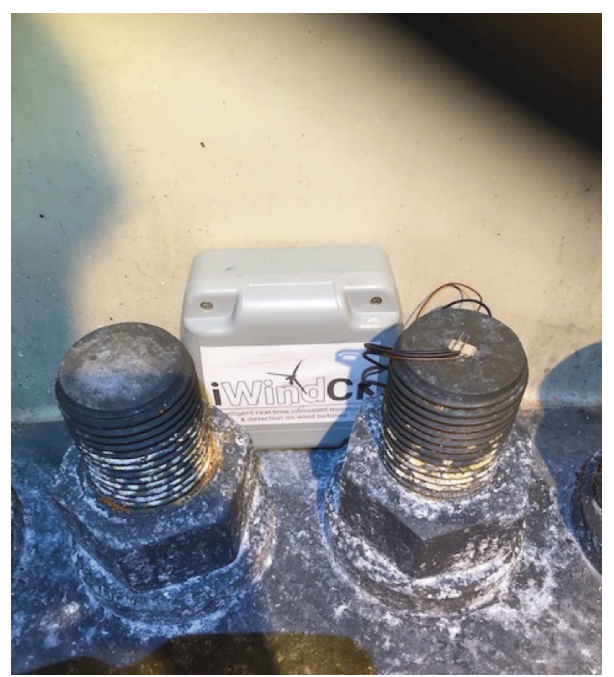

Fig.3: $i$ WindCr system set-up in the MP-TP flanged connection location with the sensor attached to the M72 stud

From the $i W i n d C r$ in-house performance testing, in order to perform a valid OCP and ZRA electrochemical analysis, it was required to obtain a minimum of 50 data per reading in a period of no less than 120 seconds. Based on this, the sensor data collection time for this field test was set out to be of 200 seconds at every 15 minutes interval of which the nanotimer was set-up. The sensor system outputs will be voltage (V) and current density $\left(\mathrm{A} / \mathrm{cm}^{2}\right)$, respectively in association with the OCP and ZRA technique analysis that are utilised in the system. Table 2 highlights the OCP and ZRA electrochemical analysis techniques. The data are collected and stored in an SD card. A battery was used to power the system up to approximately 3-4 weeks. 
Table 2: OCP and ZRA technique analysis

\begin{tabular}{|c|c|c|}
\hline & $\mathrm{OCP}$ & ZRA \\
\hline $\begin{array}{l}\text { Non-destr } \\
\text { technique }\end{array}$ & tive, passive & $\begin{array}{l}\text { Non-destructive, } \\
\text { passive technique }\end{array}$ \\
\hline $\begin{array}{l}\text { Provide in } \\
\text { fresh meta } \\
\text { potential; } \\
\text { determini } \\
\text { corrosion }\end{array}$ & $\begin{array}{l}\text { formation of a } \\
\text { l corrosión } \\
\text { tot suitable for } \\
g \text { the rate of }\end{array}$ & $\begin{array}{l}\text { Measure directly } \\
\text { the stable current } \\
\text { density in a } \\
\text { corrosion system }\end{array}$ \\
\hline$E=E^{o}+\frac{h}{r}$ & $\frac{\times T}{\times F} \log \left(\frac{\left[C_{O}{ }^{n o}\right]}{\left[C_{r}{ }^{n r}\right]}\right)$ & $\begin{array}{l}I_{\text {corr }}=I_{R . M . S} \\
=\sqrt{\frac{\sum_{1}^{n} I_{n}^{2}}{n}} \\
\text { Equation (2) }\end{array}$ \\
\hline \multicolumn{3}{|c|}{ Nomenclature: } \\
\hline$E$ & \multicolumn{2}{|l|}{ Potential. } \\
\hline$E^{o}$ & \multicolumn{2}{|c|}{ Standard Potential. } \\
\hline$R$ & \multicolumn{2}{|c|}{ Gas Constant $\left(8.314 \mathrm{~J} . \mathrm{mol}^{-1} \cdot \mathrm{K}^{-1}\right)$} \\
\hline$T$ & \multicolumn{2}{|l|}{ Temperature. } \\
\hline$n$ & \multicolumn{2}{|c|}{$\begin{array}{l}\text { Number of Electrons transferred in } \\
\text { the Corrosion Reaction. }\end{array}$} \\
\hline$F$ & \multicolumn{2}{|c|}{ Faraday Constant (96485 C/mol). } \\
\hline$C_{r}$ & \multicolumn{2}{|c|}{ The reduced species concentration. } \\
\hline$C_{o}$ & \multicolumn{2}{|c|}{ The oxidised species concentration. } \\
\hline$n_{o}$ and $n_{r}$ & \multicolumn{2}{|c|}{$\begin{array}{l}\text { oxidised species and of the reduced } \\
\text { species, respectively }\end{array}$} \\
\hline$I_{\text {corr }}$ & \multicolumn{2}{|c|}{ Corrosion Current Density } \\
\hline$I_{n}$ & \multicolumn{2}{|c|}{$\begin{array}{l}\text { Stable Current Density at certain } \\
\text { Number, } n \text { of Measurement. }\end{array}$} \\
\hline$I_{R . M . S}$ & \multicolumn{2}{|c|}{$\begin{array}{l}\text { Root Mean Square of the Current } \\
\text { Density }\end{array}$} \\
\hline
\end{tabular}

\section{In-house Laboratory Testing for Corrosion Threshold Data Generation}

\subsection{Experimental Procedure}

The in-house corrosion laboratory testing has been carried out to determine corrosion threshold values of the 10.9 Galvanised Steel, representing the M72 stud's material in the artificial seawater (SW) environment. The test was performed in accordance to [ASTM D1141 2013] at room temperature and at $\mathrm{pH}=8.3$. Table 3 outlines further detail on the laboratory testing/experiment.
Table 3: 10.9 Galvanised Steel In-house Laboratory Corrosion Testing

\begin{tabular}{|c|c|}
\hline \multicolumn{2}{|r|}{ Experimental set-up } \\
\hline Test samples: & $\begin{array}{l}\text { Size: } 2.0 \mathrm{cmX} 2.0 \mathrm{cmX} 0.3 \mathrm{~cm} ; \\
\text { Exposed Area: } 0.17 \mathrm{~cm}^{2}\end{array}$ \\
\hline Mate & 10.9 Galvanised Steel \\
\hline $\begin{array}{l}\text { Environment } \\
\text { \& Conditions }\end{array}$ & $\begin{array}{c}\text { Artificial Seawater, } \mathrm{pH}=8.3 \text {, } \\
\text { Temperature }=298 \mathrm{~K} . \\
\text { Frequencies range: } 0.01-30000 \\
\text { Hz. } \\
\text { Potential amplitude: } 10 \mathrm{mV} \\
\text { (r.m.s). } \\
\text { Total points: } 70 . \\
\text { Points/decade: } 10 .\end{array}$ \\
\hline Standards & ASTM D1141 \\
\hline Equipment & $\begin{array}{l}\text { Potentio/Galvanostat: GillAC, } \\
\text { ACM Instruments, Software: } \\
\text { Gill AC serial no } 600 .\end{array}$ \\
\hline Elec & $\begin{array}{l}\text { Reference electrode: } \mathrm{Ag} / \mathrm{AgCl} \\
\text { (KCl Saturated). Counter } \\
\text { electrode: Graphite Rod, } \\
\text { Working electrode: Test } \\
\text { samples. }\end{array}$ \\
\hline Samples & $\begin{array}{l}\text { 1. } \begin{array}{l}\text { As-received/Non-corroded } \\
\text { sample }\end{array} \\
\text { 2. Artificially corroded sample } \\
\text { using the Potentiodynamic } \\
\text { Polarisation Curves (PPC) } \\
\text { technique } \\
\text { 3. Artificially/mechanically } \\
\text { damaged (scratched) non- } \\
\text { corroded sample } \\
\text { 4. Artificially/mechanically } \\
\text { damaged (scratched) } \\
\text { corroded sample }\end{array}$ \\
\hline $\begin{array}{l}\text { Method of } \\
\text { analysis }\end{array}$ & $\begin{array}{l}\text { Electrochemical Impedance } \\
\text { Spectroscopy (EIS) }\end{array}$ \\
\hline
\end{tabular}

The Nyquist diagram which is a parametric plot of a frequency, and Bode diagrams that plot gain and phase responses of all the 10.9 Galvanised Steel test samples are shown in Figures $\mathbf{4}$ and 5. 

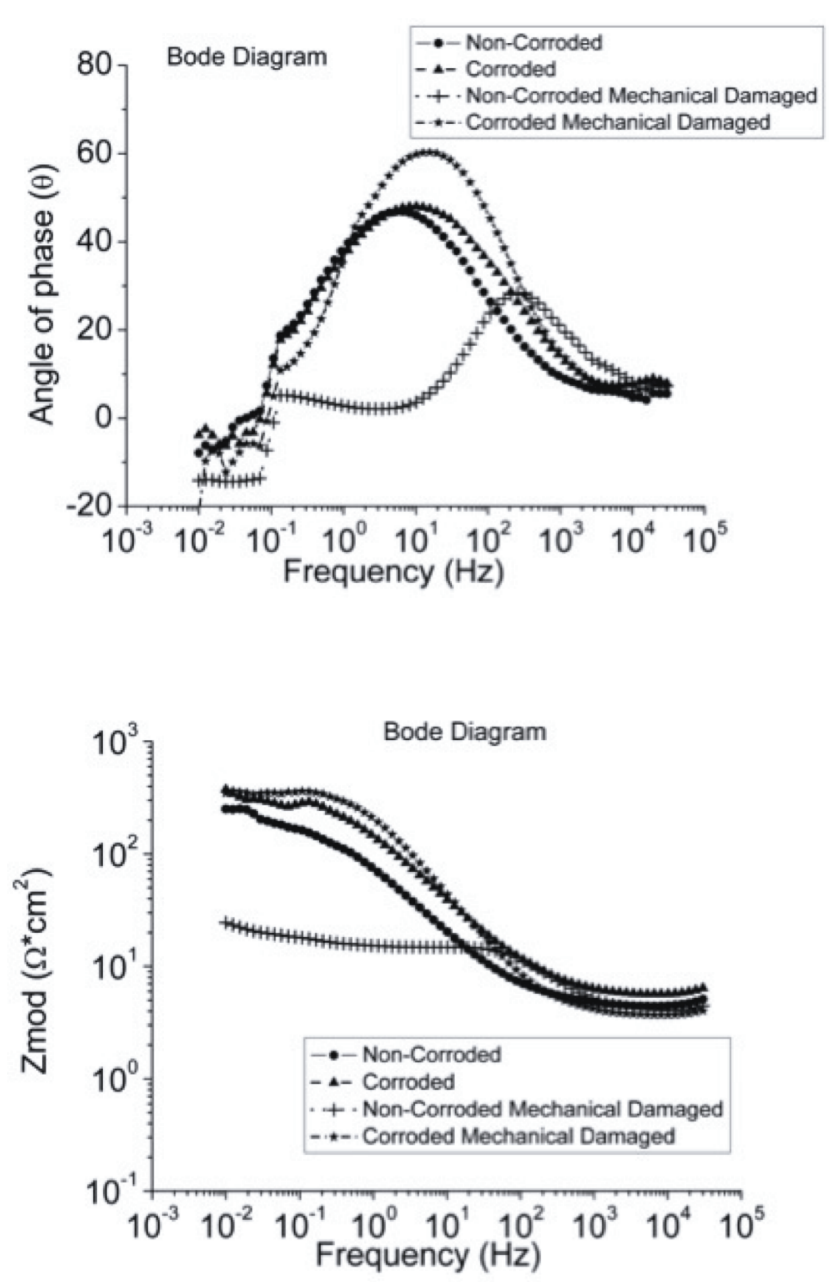

Fig.4: Bode Diagrams of the 10.9 Galvanised Steel Samples from the EIS analysis following the artificial seawater (SW) immersion testing

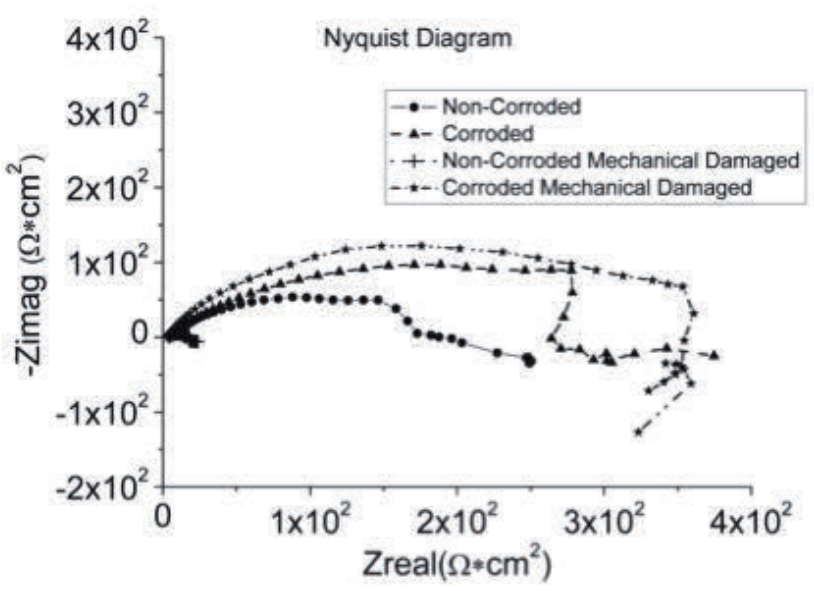

Fig.5: Nyquist Diagram of the 10.9 Galvanised Steel Samples from the EIS analysis following the artificial seawater (SW) immersion testing

\section{Field Test Data Analysis and Verification}

The field data shows that the $i W i n d C r$ system was piloted for a more and less 30-day period (March to April). From the understanding of the position where the MP-TP flanged connection is within the offshore WT and the local tidal wave data during the field study period, the studs would have not experienced a full seawater immersion. The observation at the field test location suggests that the studs would have more likely been exposed to saltwater spray or moisture.

Table 4 outlines the summary of the sensor interface system (nanotimer) field test performance. Included in Table $\mathbf{4}$ are the outcomes of the OCP and ZRA analysis, showing the calculated average potential and average current density that were derived from the raw data recorded during the field test period. The average standard deviation current density indicates the error tolerance of the system. The raw recorded data are represented in Figures 6 to 8.

Table 4: Summary of the Field Test Performances and Outcomes of the OCP and ZRA analysis

\begin{tabular}{|c|c|}
\hline $\begin{array}{c}\text { Field test performances and } \\
\text { data }\end{array}$ & Value \\
\hline $\begin{array}{c}\text { Nanotimer wake interval } \\
\text { (average, second) }\end{array}$ & $\begin{array}{c}886 \text { (at } 15 \\
\text { minutes } \\
\text { interval) }\end{array}$ \\
\hline $\begin{array}{c}\text { Sensor interface uptime } \\
\text { (minimum, second) }\end{array}$ & 250 \\
\hline $\begin{array}{c}\text { Total time between reading } \\
\text { (second) }\end{array}$ & 1136 \\
\hline Average Potential $(\mathrm{V})$ & $2.6966 \mathrm{E}-02$ \\
\hline $\begin{array}{c}\text { Standard Deviation Potential } \\
(\mathrm{V})\end{array}$ & $3.7040 \mathrm{E}-03$ \\
\hline $\begin{array}{c}\text { Average Current Density } \\
\left(\mathrm{A} / \mathrm{cm}^{\wedge} 2 \text { ) }\right.\end{array}$ & $1.7195 \mathrm{E}-10$ \\
\hline $\begin{array}{c}\text { Standard Deviation Current } \\
\text { Density }\left(\mathrm{A} / \mathrm{cm}^{\wedge} 2 \text { ) }\right.\end{array}$ & $1.4854 \mathrm{E}-09$ \\
\hline Corrosion Rate $(\mathrm{cm} / \mathrm{s})$ & $4.1401 \mathrm{E}-15$ \\
\hline
\end{tabular}

The corrosion threshold values ( $\mathrm{iWindCr}$ database) obtained from the in-house laboratory corrosion tests for the 10.9 Galvanised Steel alloy are used to verify the electrochemical or corrosion state of the stud. The average voltages and current densities from the database are compared with the OCP and ZRA data from the field test.

As shown in Table 5, the database from the inhouse corrosion test of the 10.9 Galvanised Steel showed different average voltage and current 
density levels (different order of magnitude) to the data obtained from the field test. This would be expected as the 10.9 Galvanised Steel's threshold values obtained from the in-house laboratory testing conditioned the full surface immersion in seawater. This was not the case during the field test where the surface of the stud was mainly exposed to saltwater spray or moisture. The salt spray corrosion threshold values of the 10.9 Galvanised Steel was not currently available.

The average voltage and current density values from the field test appeared to be more comparable with the threshold values of the alloys that have a type of protective film. This film could be resulted from oil or grease covering the surface of the alloy. In conjunction with the presence of the thin passive film on the surface of the stainless steel, the 316 stainless steel threshold values derived from the salt spray corrosion testing showed similarities in the average voltage and current density values from the field test. This seems to support the information given by the WT operator with regards to the used of (Molykote) coating on the M72 stud. However, a chemical compositional analysis would be needed to confirm it. Because of the stud was made of low carbon steel (10.9), the corrosion threshold values of the S235, a low carbon steel alloy (a weathering steel) were also referred to and compared with the field test data. For the references, Table 6 lists the conditions and the experimental standards used to generate the inhouse corrosion threshold values i.e. the $i \mathrm{WindCr}$ database.

By referring to similar conditions and type of materials, the voltages and current density evaluated from the field test suggested that there is no general corrosion as well as localised corrosion detected on the M72 stud during this pilot study period.

The field test average current density and sensor characteristic values given in Table 3 could also be used to estimate the corrosion rate, $C R(\mathrm{~cm} / \mathrm{s})$. The $C R$ is derived using Equation (3).

$$
C R=\frac{I_{A v e * M}}{F * n_{e^{* \rho}}} \quad \text { Equation (3) }
$$

where: $M=$ molecular mass $(\mathrm{g} / \mathrm{mol}), F=$ constant of Faraday $(96,485 \mathrm{C} / \mathrm{mol}), n_{e}=$ number of transferred electrons in redox reaction, and $\rho=$ density of the material $\left(\mathrm{g} / \mathrm{cm}^{2}\right)$. The pilot study estimated a very low corrosion rate, indicating that there was no accelerated corrosion monitored in this trial period.

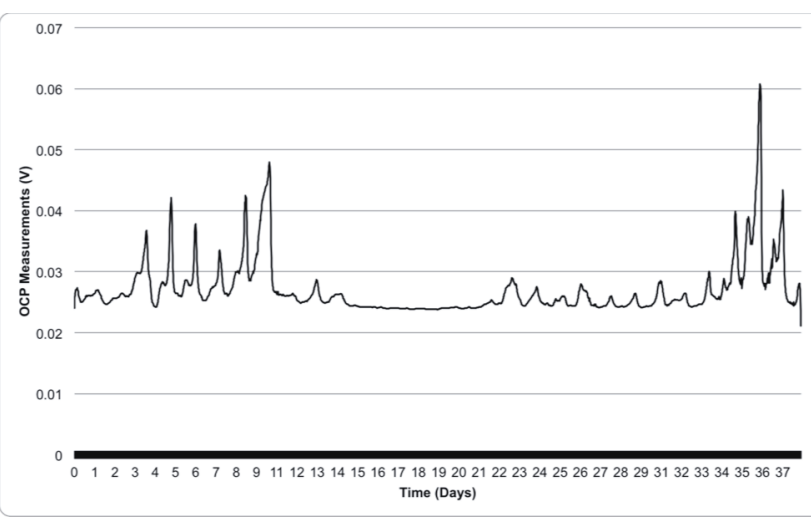

Fig.6: OCP (raw data) measurement plot

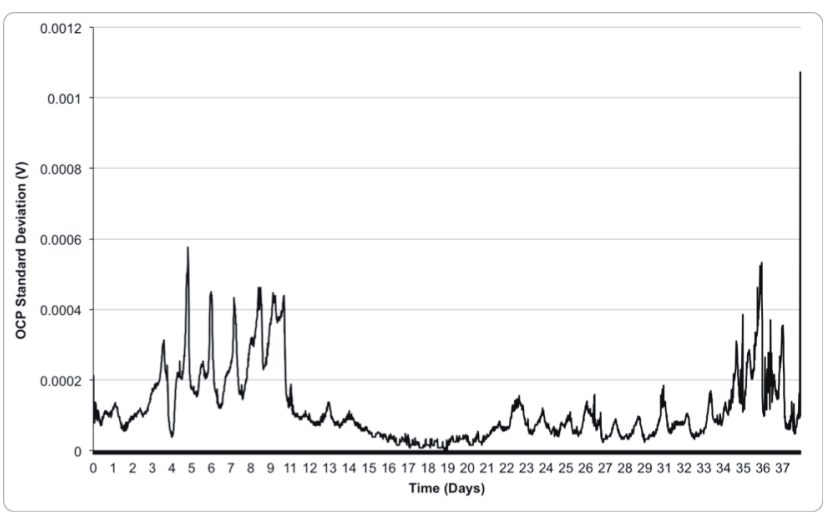

Fig.7: OCP (raw data) Standard Deviation Plot

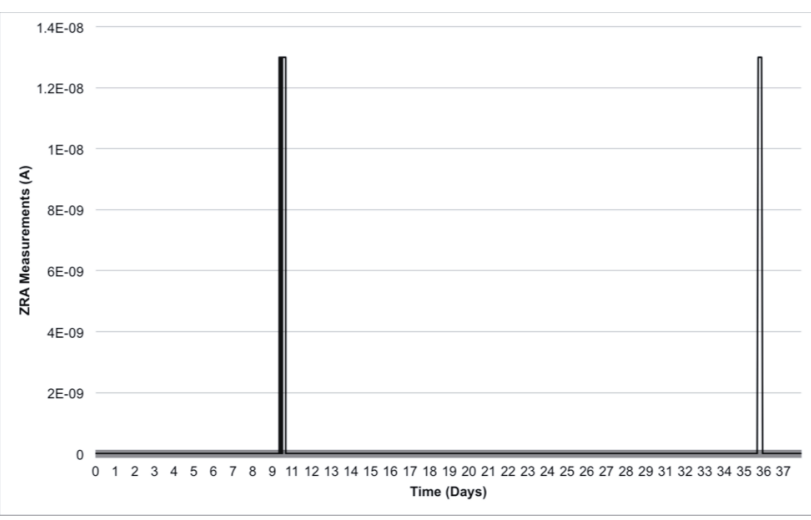

Fig.8: ZRA (raw data) Measurement plot

\section{Conclusion}

A pilot study (a field test) on the $i$ WindCr WSN system on one of the offshore WT structures has been conducted. Albeit the system was only installed on one of the MP-TP flanged connection 
studs for only a limited period of time, this field test has demonstrated the full functionality of the design and the stability of the prototype system with regards to corrosion detection and monitoring. This gives the confidence to further develop the system towards commercialization.

Table 5: Potential and Current Density values of selected steel alloys

\begin{tabular}{|c|c|c|c|}
\hline Alloy & Environment & $\begin{array}{c}\text { Potential } \\
\text { (V) }\end{array}$ & $\begin{array}{l}\text { Current } \\
\text { density } \\
\left(\mathrm{A} / \mathrm{cm}^{2}\right)\end{array}$ \\
\hline $\begin{array}{l}\text { M72 } \\
\text { stud }\end{array}$ & $\begin{array}{c}\text { Salt Spray } \\
\text { (SS) or } \\
\text { Moisture }\end{array}$ & 0.0270 & $1.7 \mathrm{E}-10$ \\
\hline $\begin{array}{c}10.9 \\
\text { Galvanis } \\
\text { ed Steel }\end{array}$ & $\begin{array}{c}\text { Seawater } \\
(\mathrm{SW})\end{array}$ & $\leq-1.000$ & $\geq 8 \mathrm{E}-05$ \\
\hline SS316L & SS & $\begin{array}{l}\leq 0.030 \\
\geq 0.050\end{array}$ & $\geq 2 \mathrm{E}-09$ \\
\hline \multirow{5}{*}{ S235 } & $\begin{array}{c}\text { Grease } \\
\text { Lubricant } \\
(\mathrm{GL})\end{array}$ & $\begin{array}{l}\leq-0.120, \\
\geq 3.000 ¥\end{array}$ & $\geq 2 \mathrm{E}-09$ \\
\hline & SW & $\begin{array}{l}\leq-0.720 \\
\geq-0.600\end{array}$ & $\geq 1 \mathrm{E}-05$ \\
\hline & $\begin{array}{c}\mathrm{GL}+\mathrm{SW} \text { at } \\
298 \mathrm{~K}\end{array}$ & $\begin{array}{l}\leq-0.150 \\
\geq 3.000\end{array}$ & $\geq 3 \mathrm{E}-08$ \\
\hline & $\begin{array}{l}\text { Oil Lubricant } \\
(\mathrm{OL}) \text { at } 298 \mathrm{~K}\end{array}$ & $\begin{array}{l}\leq 1.180 \\
\geq 3.000\end{array}$ & $\geq 2 \mathrm{E}-10$ \\
\hline & SS & $\begin{array}{l}\leq-0.390 \\
\geq-0.120\end{array}$ & $\geq 2 \mathrm{E}-07$ \\
\hline
\end{tabular}

There are of course some improvements needed especially with regards to lowering the system's power and current consumptions and perhaps scaling down the system. A follow-up trial would be needed to test the stability and reliability of the sensor for example with regards to the WSN communication between turbines. Although the current $i W i n d C r$ corrosion database has been developed for the offshore WT structures however its usage can be adapted for other applications such as for marine structures or vessels. It needs to be further expanded to include more materials including coated ones since the threshold values are strongly dependence on the materials and the environments/conditions. The media or environments that the materials are exposed to, such as seawater, oil, moisture or salt spray would result in a different electrochemical or corrosion activities and types.

Although, it has been shown in this paper that $i W i n d C r$ system could be used to estimate the corrosion rate hence predict the life of the component, this work was performed for the purpose of $i$ Wind $C r$ system pilot study only and should not be used for a structural judgment of the relevant WT.

Table 6: Conditions and Standards for the $i$ Wind $C r$ database

\begin{tabular}{|c|c|c|}
\hline Environment & Conditions & Standard \\
\hline \multirow[b]{2}{*}{ Artificial SW } & Immersion $40 \mathrm{~mL} / \mathrm{cm}^{2}$ & \multirow{2}{*}{$\begin{array}{c}\text { [ASTM } \\
\text { D1141, } \\
2013]\end{array}$} \\
\hline & $\mathrm{pH}=8.2$ at $\mathrm{T}=298 \mathrm{~K}$ & \\
\hline \multirow{4}{*}{$\mathrm{OL}$} & Immersion & \multirow{4}{*}{$\begin{array}{c}\text { [ASTM } \\
\text { D6547, } \\
2016]\end{array}$} \\
\hline & $\begin{array}{l}\text { Poly-Alpha- } \\
\text { Olephine }\end{array}$ & \\
\hline & $\mathrm{pH}=8.8$ at $\mathrm{T}=298 \mathrm{~K}$ & \\
\hline & $\mathrm{pH}=8.6$ at $\mathrm{T}=328 \mathrm{~K}$ & \\
\hline \multirow{3}{*}{$\begin{array}{c}\text { GL:SW } \\
(30: 70) \text { in } \\
(\mathrm{Wt} / \mathrm{Wt})\end{array}$} & Immersion & \multirow{3}{*}{$\begin{array}{c}\text { [ASTM } \\
\text { D665, } \\
2014]\end{array}$} \\
\hline & $\mathrm{pH}=4.3$ at $\mathrm{T}=298 \mathrm{~K}$ & \\
\hline & $\mathrm{pH}=6.8$ at $\mathrm{T}=328 \mathrm{~K}$ & \\
\hline \multirow{5}{*}{ SS } & $\begin{array}{l}\text { Dissolution; Salt } \\
\text { Water mass } 5 \%\end{array}$ & \multirow{5}{*}{$\begin{array}{c}\text { [ASTM } \\
\text { B117, } \\
2018]\end{array}$} \\
\hline & Pressure; $83 \mathrm{KPa}$ & \\
\hline & Fog Volume: $80 \mathrm{~cm}^{3}$ & \\
\hline & $\mathrm{pH}=7$ at $\mathrm{T}=308 \mathrm{~K}$ & \\
\hline & $\begin{array}{l}\text { Mode: Continuous } \\
\text { (for } 96 \text { hours) }\end{array}$ & \\
\hline
\end{tabular}

\section{Acknowledgments}

This work was supported by the Innovate UK $i$ Wind Cr Project (Grant Number 103504) and cofunded by our industrial partners Avonwood Development Ltd (Co. No. 02570711) and Avanti Communication Plc (Co. No. 03101607). The authors would also like to acknowledge the Faculty of Technology and the School of Engineering, University of Portsmouth for their support in this work.

\section{References}

Ahuir-Torres JI, Bausch N, Farrar A, Simandjuntak S, Nash A, Thomas B, Muna J, Jonsson C, Mathew D (2019). Benchmarking 
parameters for remote electrochemical corrosion detection and monitoring of offshore wind turbine structures. Wind Energy. 22: 857-876.

Ancona D, McVeigh J (2001). Wind TurbineMaterials and Manufacturing Fact Sheet, J.of Wind Turbine-Materials and Manufacturing Fact Sheet, Vol. 19. Rockville, Maryland, USA: Princeton Energy Resources International, LLC.

ASTM. Standard Practice for Operating Salt Spray (Fog) Apparatus. ASTM-B117. 2018

ASTM. Standard Practice for the Preparation of Substitute Ocean Water. ASTM-D1141. 2013.

ASTM. Standard Test Method for Corrosiveness of Lubricanting Fluid to Bimetallic Couple. ASTM-D6547. 2016.

ASTM. Standard Test Method for RustPreventing Characteristics of Inhibited Mineral Oil in the Presence of Water. ASTM-D665. 2014.

Black AR, Mathiesen T, Hilbert LR (2015) Corrosion protection of offshore wind foundations. Houston, TX, USA: NACE International.
Dow Corning (2012). Molykote. Lubrication solutions for threaded connections. Dow Corning Corporation.DNVGL-RP-0416 (2016). Corrosion protection for wind turbine. Norway, DNV GLMarch, 2016.

DNV-OS-J101 (2013) Design of Offshore Wind Turbine Structures. Offshore Standard DNV-OSJ101. Det Norske Veritas, January 2013Estate C (2010) A guide to an offshore wind farm. Power. $1-70$.

Pawsey C (2016). Corrosion protection for offshore wind, prevention and aftercare: meet the industry players. 4th International Conference Corrosion Protection for Offshore Wind; Berlin, Germany

RenewableUK (2019). Retrieved from:

https://www.renewableuk.com/page/WindEnergy (on 15 th August 2019)

UKWED (2019). Retrieved from: https://www.renewableuk.com/page/UKWEDhom e (on $15^{\text {th }}$ August 2019) 